\title{
Research
}

\section{Consequences of Environmental Service Payments for Forest Retention and Recruitment in a Costa Rican Biological Corridor}

\author{
Wayde C. Morse $^{1,2}$, Jessica L. Schedlbauer ${ }^{1,2}$, Steven E. Sesnie ${ }^{1,2}$, Bryan Finegan ${ }^{1}$, Celia A. Harvey ${ }^{1,3}$, \\ Steven J. Hollenhorst ${ }^{2}$, Kathleen L. Kavanagh ${ }^{2}$, Dietmar Stoian ${ }^{1}$, and J. D. Wulfhorst ${ }^{2}$
}

\begin{abstract}
Compensation to landowners for forest-derived environmental services has gained international recognition as a mechanism to combat forest loss and fragmentation. This approach is widely promoted, although there is little evidence demonstrating that environmental service payments encourage forest stewardship and conservation. Costa Rica provides a unique case study in which a 1996 Forestry Law initiated environmental service payments and prohibited forest conversion to other land uses. We examined these novel policies to determine their influence on landowner decisions that affect forest change, carbon services, and connectivity in a $2425 \mathrm{~km}^{2}$ biological corridor. We used Landsat images to compare land-cover changes before and after 1996, and linked these data to landowner surveys investigating land-use decisions. Carbon stocks and storage in secondary forests were also examined. Forest change observations were corroborated by landowner survey data, indicating that the 1996 Forestry Law and environmental service payments contributed positively to forest retention and recruitment. Socioeconomic conditions also favored forest protection. Rates of natural forest loss declined from $-1.43 \%$ to $-0.10 \% / y r$ after 1996. Forest cover and connectivity were maintained through tree plantations and secondary forest recruitment, although forest heterogeneity increased as these forest types sometimes replaced natural forest. Carbon storage in secondary forest approached levels in primary forest after 25-30 yr of succession, although few landowners retained natural regeneration. Secondary forests will persist as minor landscape components without legal or financial incentives. The Costa Rican experience provides evidence that environmental service payments can be effective in retaining natural forest and recruiting tree cover within biological corridors.
\end{abstract}

Key Words: biological corridor; carbon storage; Costa Rica; environmental service payments; forest change; landowner decision making; Sarapiquí; secondary forest

\section{INTRODUCTION}

Forest loss and fragmentation represent a global threat to biodiversity, ecosystem processes, and human welfare (Millennium Ecosystem Assessment 2005). Demands on forests and the environmental services they provide are projected to increase as land-use pressure reduces the amount of remaining private forest lacking protected status (Defries et al. 2005). In response to these threats, incentive programs encouraging private forest stewardship have emerged, offering compensation to landowners to retain forests and associated services that might otherwise be lost to alternative land uses (Pagiola et al. 2002). Direct payments to landowners to plant or protect forests are promoted as an effective mechanism for providing environmental services (Ferraro and Kiss 2002) consistent with the 1992 Convention on Biological Diversity. However, the effects of these payments on forest cover and environmental services remain relatively unknown.

Costa Rica presents an opportunity to examine the impacts of an environmental service payment program, pago por servicios ambientales (PSA), that currently provides direct payments to landowners for reforestation and natural forest protection. Reforestation incentives for private landowners were first initiated in Costa Rica following several decades of high deforestation (Watson et al. 1998). During the mid-1980s, tradable bonds and upfront payments were offered to landowners to cover the costs of establishing and maintaining tree plantations (Watson et al. 1998). Additional incentives initiated in 1990 targeted sustainable forest management and were expanded in 1995 to include forest protection. Costa Rica built on the legacy of these programs with the 1996 
Forestry Law (no. 7575), which implemented four novel features including: (1) a national definition of forest, (2) prohibition of natural forest conversion to any other land use, (3) deregulation of tree plantation management, and (4) a voluntary PSA program to compensate landowners for providing these environmental services: watershed protection, biodiversity conservation, carbon sequestration, and aesthetic values. These policies were specifically tailored to the country's socioeconomic, forest, and land-use conditions.

A national legal definition of forest has made it plain what constitutes natural forest, regenerating forest, and tree plantations. This definition has direct consequences on efforts to maintain and recover forest land and related environmental services, because natural forest can no longer be legally cleared. Further, if agricultural land is abandoned, successional vegetation becomes a permanent landscape feature when it reaches a stage that meets the legal definition of forest. In return, the Forestry Law provides monetary compensation to landowners through PSA for natural forest protection to partially offset the loss of alternate land uses that may degrade environmental services. The deregulation of tree plantation management was designed to promote reforestation as an economically viable activity while also sequestering carbon and protecting native biodiversity (Watson et al. 1998).

Legal and institutional support for the PSA program is provided by the National Fund for Forest Financing (FONAFIFO), a governmental organization designed to promote sustainable rural development among small and medium-sized land ownerships (Snider et al. 2003). National PSA priorities have concentrated efforts in biological corridors and poorly developed regions of the country with more than U.S. $\$ 169$ million expended on $>5300 \mathrm{~km}^{2}$ of land between 1995 and 2007 (FONAFIFO 2008). To date, > 6000 PSA contracts have been initiated nationwide in three program areas: natural forest protection, reforestation, and forest management. Payments are made on a per hectare basis, last for $5 \mathrm{yr}$, and range from a total of $\$ 320 /$ ha for forest protection to $\$ 816 /$ ha for reforestation (FONAFIFO 2008). Payments for natural forest management were discontinued in 2002. Approximately $15 \%$ of payments to landowners are used to fund an initial management plan and subsequent monitoring required by the PSA program (Pagiola 2008). Contract agreements with landowners are facilitated by an accredited forester called a regente, often from an intermediate NGO. PSA contracts are legally binding, and compliance monitoring is the responsibility of the regente with oversight from the national Ministry of Environment and Energy (MINAE). These steps add flexibility to program implementation and reduce transaction costs by making private organizations and professionals accountable for this process (Chomitz et al. 1999).

Although the objectives of 1996 Forestry Law and PSA are to provide environmental services through forest stewardship, their impacts on forest change, carbon services, and connectivity in targeted corridor areas are unclear. Further, the influence of forest policies and programs on landowner decisions to maintain or increase forest cover remains poorly understood. Accordingly, we applied an integrated approach to determine the extent to which the 1996 Forestry Law and PSA incentives for landowners to maintain or replant forests have influenced forest cover, carbon services, and connectivity. We studied these attributes in the San Juan-La Selva Biological Corridor, a PSA focal area designed to enhance forest linkages and opportunities for species movement between protected areas in Costa Rica and southern Nicaragua (Fig. 1).

Studies of land-cover change detection, rural sociology, and ecosystem ecology were combined to address questions in three focal areas:

1. Forest retention. Has the rate of forest loss declined for private forest land in the Corridor since the implementation of the 1996 Forestry Law? To what extent are changes in forest cover attributable to the ban on forest clearing and PSA to protect forests?

2. Forest recruitment. Have PSA incentives for reforestation been a catalyst for forest recruitment? What is the outlook for recruiting forest cover via secondary succession as a potential source of valued carbon services under the 1996 Forestry Law?

3. Forest connectivity. Are the land-use policies of the 1996 Forestry Law and PSA effective in retaining forest connections important for biodiversity between protected areas? 
Fig. 1. Map of the San Juan-La Selva (SJLS) Biological Corridor. Depicted natural forest cover is for year 2000 (ITCR 2004).

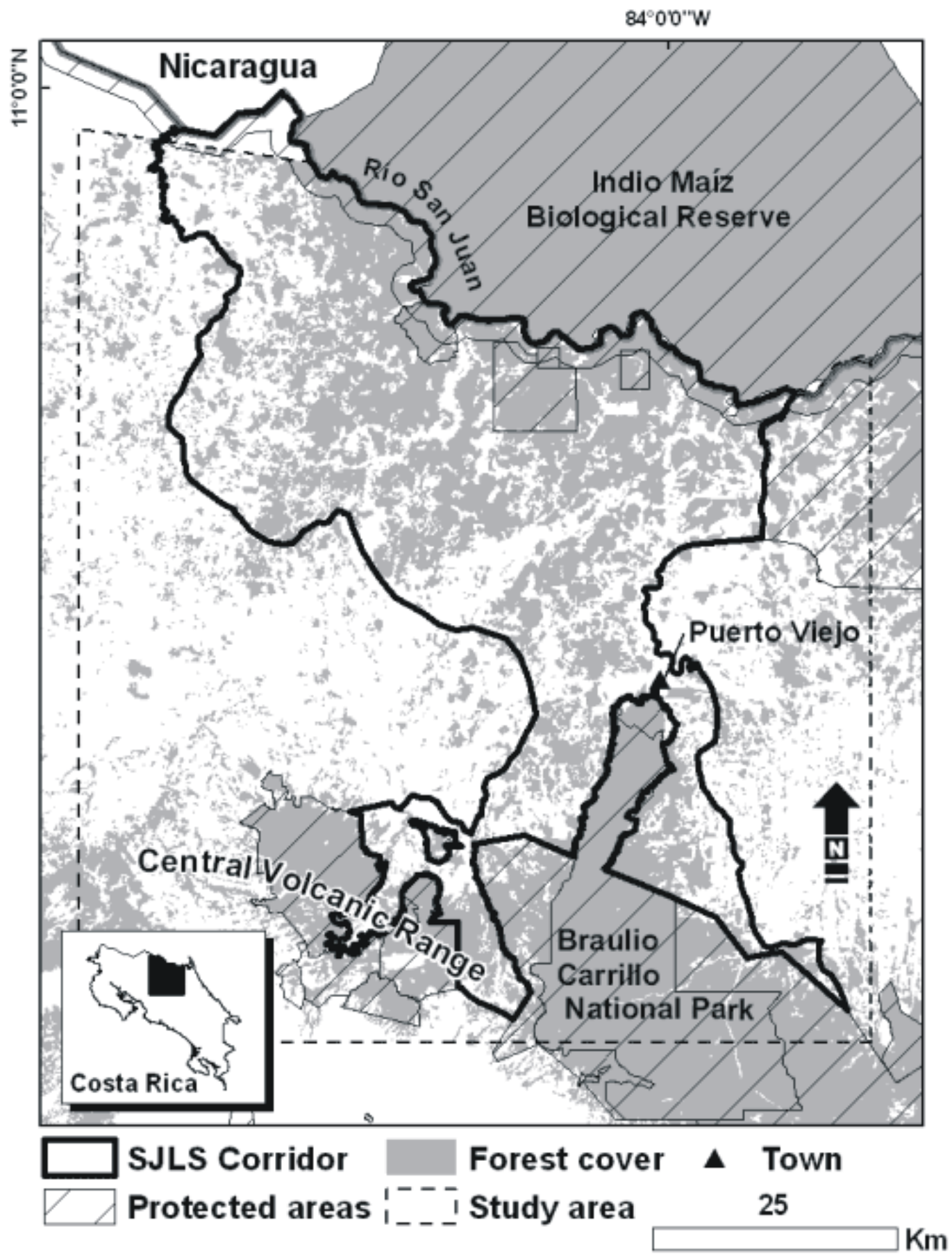




\section{METHODS}

\section{Study area}

The research was conducted in the $2425-\mathrm{km}^{2}$ San Juan-La Selva Biological Corridor in northern Costa Rica where, as of 2001, PSA contracts occurred on $30 \%\left(729 \mathrm{~km}^{2}\right)$ of the land area. A larger surrounding study area of $6349 \mathrm{~km}^{2}$ was selected to facilitate forest change comparisons in areas of lower PSA priority that border the Corridor. In 2001, this larger study area had PSA contracts on $11 \%$ $\left(421 \mathrm{~km}^{2}\right)$ of its land area according to FONAFIFO contract records (Fig. 1). Costa Rican NGOs have been instrumental in promoting PSA programs to maintain and restore forest connectivity in the anthropogenically fragmented Corridor landscape. The Foundation for Sustainable Development of the Central Volcanic Range (FUNDECOR) and the Forestry Development Commission of San Carlos (CODEFORSA) initiated > 400 PSA contracts with landowners between 1996 and 2005 (Chomitz et al. 1999, Zbinden and Lee 2005).

The Corridor contains one of Costa Rica's largest aggregations of private forest outside protected areas (Watson et al. 1998) and represents an important connection between formerly continuous montane and lowland forest (Butterfield 1994a). Forest in the Corridor occurs across five Holdridge Life Zones and three transitional zones, designations based on the region's varied macroclimatic conditions (Holdridge 1967). The Corridor initiative is aimed at retaining biodiversity across this gradient of habitats (Chassot and Monge 2002). Rapid land-use change has occurred in the study area since its opening as an agricultural frontier in the 1950s (Butterfield 1994b). Forests were initially cleared to make way for cattle pastures, although more recent changes rapidly increased landscape heterogeneity as agricultural crops such as sugar cane, bananas, and pineapple were introduced (Read et al. 2001, Sesnie et al. 2008).

\section{Forest and land-cover change}

We selected five Landsat Thematic Mapper (TM) satellite images, WRS Path 15 Row 53 (U.S. Geological Survey, Reston, Virginia, USA), with low cloud cover from the years 1986, 1996-1997, and 2001 to quantify land-cover changes before and after implementation of the 1996 Forestry Law. We refer to the time period before 1996 (1986-1996) as T1 and the period afterward (1996-2001) as T2. A categorical land-cover change detection method was used to reduce the atmospheric impacts that occur in humid environments (Lu et al. 2003). ENVI v. 4.1 image processing software (Research Systems, Inc., Boulder, Colorado, USA) was used to prepare and classify images. Images were individually co-registered to a 1996 TM image referenced to ground locations for spatially accurate comparisons.

The categories used to analyze the land-cover changes detected were chosen based on recent landcover studies in northern Costa Rica (Pedroni 2003). Five forest categories were used for change detection analyses, including: (1) natural forest, i. e., closed canopy or selectively logged old-growth forest and natural palm swamps; (2) a charral phase of native shrub and herbaceous regeneration; (3) secondary forest dominated by regenerated native trees aged 15-20 yr; (4) tree plantations composed mainly of traditional single species exotic or native reforestation; and (5) riparian forest, i.e., linear forest arrangements along $>$ second-order streams. It should be noted that Landsat TM imagery is unlikely to discriminate secondary forest from latesuccessional forest in this landscape because the forest canopy closes after 15-20 yr. However, secondary forest aged more than $20 \mathrm{yr}$ was uncommon in the study area (Read et al. 2001). We also identified two agricultural land-use categories: pastures and annual or perennial crops such as pineapple, sugar cane, bananas, and heart of palm. The spatial grain of each land-cover category was set at a minimum mapping unit of 1 ha.

A "supervised" image classification method was implemented to map land-cover categories for each image date using the Quick, Unbiased, Efficient, Statistical Tree (QUEST) algorithm (Loh and Shih 1996). Training information for each land-cover type used to develop classification tree models was taken from aerial photos, forest inventory maps, and ground reference points collected in the field. For this study, nonparametric QUEST classification trees were applied to distinguish land-cover types. Both categorical and continuous predictor variables can be used in these analyses. Predictors such as elevation, topographic moisture index, percent slope derived from a 90-m digital elevation model, and the Normalized Difference Vegetation Index were used in addition to TM bands $1-5$ and 7 to enhance discrimination among land-cover types. 
Image classification accuracy was evaluated using a cross-validation with ground reference data for each land-cover type. A 94\% overall accuracy was obtained with a difference of $\pm 3 \%$ among image dates. Forest categories had an acceptable degree of class accuracy above $80 \%$ for all image dates with the exception of riparian forest accuracy, which averaged $71 \%$.

We first used area summaries for each land-cover category and image date to compare land-use patterns between the larger case study area and the Corridor. From land-cover area estimates, differences in the annual rate of change for each forest category were used to compare retention and recruitment within the Corridor before and after the implementation of the 1996 Forestry Law. Rates of forest change for time periods $\mathrm{T} 1$ and $\mathrm{T} 2$ were estimated using the formula by Puyravaud (2003):

$$
r=\left(1 / t_{2}-t_{1}\right) * \ln \left(A_{2} / A_{1}\right)
$$

where $A_{1}$ is the forest area at the first time interval $\left(t_{1}\right)$ and $A_{2}$ is the forest area at the second time interval $\left(t_{2}\right)$. The annual rate equation provided a standard method for making land-cover change comparisons that were insensitive to the differing time periods ( $10 \mathrm{vs} .5 \mathrm{yr}$ ) between observation dates (Puyravaud 2003). Second, a post-classification image-to-image change analysis was used to determine transitions among land-cover categories through time (Lu et al. 2003).

Change in natural forest cover potentially attributed to the ban on forest clearing, and PSA for forest protection was modeled by modifying the rate equation,

$$
r^{\prime}=\left(1 / t_{2}-t_{1}\right) * \ln \left(A_{2 \mathrm{i}} / A_{1}\right)
$$

where

$$
A_{2 \mathrm{i}}=A_{2}-\left(A_{\mathrm{i}} / P_{\mathrm{i}}\right)
$$

$A_{2 \mathrm{i}}$ is estimated forest areas for $t_{2}$ assuming no PSA protection for natural forest. $A_{\mathrm{i}}$ is the total natural forest area under PSA protection between 1996 and 2001, which was $133 \mathrm{~km}^{2}$ inside the Corridor according to FONAFIFO and FUNDECOR records. $P_{\mathrm{i}}$ is the proportion of individuals enrolled in the PSA protection program who would likely convert natural forest to another land use without the 1996 law prohibiting this activity. $P_{\mathrm{i}}$ was determined from the landowner survey data described below. We assumed that all landowners indicating a preference to clear natural forest in the absence of the 1996 law would have done so by the end of $\mathrm{T} 2$.

Some illegal forest clearing continued in the region after 1996 (MINAE 2003, Schedlbauer et al. 2008). We sought to determine whether PSA payments to protect natural forest focused in the Corridor would show a greater reduction in forest clearing relative to locations in the surrounding area. To estimate the potential impact of payments on natural forest retention, differences in the amount of natural forest area cleared inside and outside the Corridor during $\mathrm{T} 1$ and T2 were compared.

Additionally, we used Wilcoxon Signed Rank tests, S-Plus, v. 6.0 (TIBCO Software Inc., Palo Alto, California, USA ), to compare the size distribution of natural forest patches $\geq 1$ ha in size that had converted from a forest type to another land-use category across T1 and T2. The FRAGSTATS spatial statistics package, v. 3.3 build 5, (University of Massachusetts, Amherst, Massachusetts, USA) was used to calculate patch cohesion, percentage of like adjacencies, and mean Euclidean nearestneighbor class metrics as indicators of connectivity, aggregation, and isolation for the Corridor. Fragmentation indices were compared across the three image dates at the landscape level and for each forest type.

\section{Landowner decision making}

We conducted household surveys to estimate the influence of forest policies and PSA incentives on landowner decisions to retain and recruit forest. Data concerning motivations for on-farm tree management of natural forest, charral, secondary forest, and tree plantations were collected. The survey also gathered information related to landowner participation in PSA, future plans for land currently enrolled in PSA, and the influence of 
PSA on land-use decisions. Landowners are actively recruited by regentes to participate in PSA but also apply based on their own initiative. Program participants were expected to be different from nonparticipants in the region (Miranda et al. 2003, Zbinden and Lee 2005), and a livelihoods analysis was used to examine differences between these groups (DFID 2003). This analysis was based on livelihood assets, i.e., the resources available to landowners when making conservation or production decisions about their land. Social, human, physical, and natural livelihoods assets were considered. Survey data were used to determine these assets and their linkages to land-use decisions that can affect changes in land cover.

We used a FONAFIFO database of all PSA participants $(n=510)$ within the Corridor to randomly select a sample of 99 households. Those receiving reforestation incentives from previous programs were included as participants because payment contracts were continued under the 1996 Forestry Law. A sample of 108 nonparticipants was selected from the 2000 Costa Rican Cattle Census and paired with participants in the same geographic area. The sample size yielded a sampling error of $\pm 10 \%$ (Salant and Dillman 1994), with six refusals. The unit of analysis was the household, and a research team administered the survey through faceto-face interviews.

Summary data, i.e., proportions, were calculated from survey questions regarding on-farm forest management and motivations to participate in PSA programs. Landowners were compared across livelihood assets to identify variables correlated with participation in the PSA program. A decision tree analysis, AnswerTree, v. 2.0 (SPSS Inc., Chicago, Illinois, USA), with the QUEST algorithm described above was used to identify the primary livelihood assets differentiating PSA participants and nonparticipants. The predictor variables or livelihood assets in this analysis included level of education; farm size; percentage of income derived from agricultural activities on the farm; location of residence, e.g., resident or absentee landowner; and number of hectares of the farm in pasture, charral, and forest.

\section{Aboveground and belowground carbon stocks in secondary forests}

Forest sites naturally regenerated on former pasture were selected to examine secondary forest development and the potential of these forests to provide environmental services through carbon storage, one of PSA's four target services. Secondary forest development was also examined as a mode of forest recruitment using landowner surveys, and the selected study sites represent charral, secondary forest, and pasture land-cover types identified in the land change detection. Study sites included: (1) three young sites in the charral phase of development, characterized primarily by shrubs and herbaceous cover; (2) nine older secondary forest sites eligible for legal classification as forest by 1996 Forestry Law standards, i.e., $70 \%$ canopy cover with 60 trees/ha $\geq 15 \mathrm{~cm}$ in diameter at breast height (dbh); and (3) four active pastures grazed for at least $18 \mathrm{yr}$. Fifteen sites were located on acidic, highly weathered Ultisols derived from volcanic parent material, and the remaining site was located on an Inceptisol derived from alluvial deposits. The unbalanced study design is primarily because of the scarcity of accessible regenerating areas, particularly charral, within the study area.

We collected soil samples at each site from four locations in each of three plots at depths of $0-10$, $10-20$, and $20-30 \mathrm{~cm}$. Three samples per depth were composited for percent soil carbon determination, and the fourth sample was used for bulk density determination. We derived soil carbon content at the Idaho Stable Isotopes Laboratory, and data are reported on a volume basis. Additional information on site selection, sampling strategy, and sample analysis appears in Schedlbauer and Kavanagh (2008).

We established three $50 \times 50 \mathrm{~m}$ plots to determine species and dbh for all trees, palms, and lianas $\geq 5$ $\mathrm{cm}$ dbh within each of the nine secondary forest sites. These plots were not identical to those from which soil was sampled. When present, dbh measurements were made above buttresses. Total aboveground biomass was estimated with these data using the equation for wet forest stands by Chave et al. (2005) that accounts for differences in wood density among species. Estimates of aboveground biomass were multiplied by 0.5 to determine aboveground carbon stocks. Remnant trees present at sites prior to pasture abandonment were defined as stems $\geq 60 \mathrm{~cm} \mathrm{dbh}$. These trees represented $<1 \%$ 
of all stems at these sites and were removed from the data set so that we could more easily evaluate aboveground carbon accumulation by new stems following pasture abandonment.

Mean soil carbon pool size was analyzed by depth class, and linear mixed-effects models (Pinheiro and Bates 2000) were used to examine changes across land-cover types, i.e., pasture, charral, and secondary forest. Significant differences among land-cover types detected with analysis of variance (ANOVA) were examined via multiple comparisons procedures. Analyses were performed with the statistical language R, v. 2.0.1 (R Core Development Team 2008). Aboveground data were examined in relation to secondary forest age, although, to avoid the problem of pseudoreplication, no statistical analyses were performed.

\section{RESULTS}

\section{Natural forest retention}

Land-cover change estimates for the Corridor showed a notable decrease in the annual rate of natural forest loss from $-1.43 \% / \mathrm{yr}$ in $\mathrm{T} 1$ to $-0.10 \%$ / yr after 1996 (Table 1). Significantly larger natural forest patches were converted to other land uses in T1 relative to T2 $(Z=15.10, P<0.001)$. Most clearing of large natural forest patches $(>150 \mathrm{ha})$ occurred prior to 1996 (67 in T1 vs. 5 in T2) and were located in the northeastern lowland portion of the Corridor (Fig. 2). Both the Corridor and the larger study area showed a greater decrease in natural forest during T1 than in T2 (Fig. 3A,B), with $61 \%$ of forest loss across both areas occurring inside the Corridor. During T2, only $7 \%$ of total natural forest loss occurred inside the Corridor relative to the larger study area landscape. Thus, forest clearing inside the Corridor was negligible in T2, and $93 \%$ of the natural forest patches illegally cleared after implementation of the 1996 law were outside of the Corridor (see also Schedlbauer et al. 2008).

Landowner survey data collected inside the Corridor showed that $64 \%$ of the sample population owned natural forest and that $55 \%$ of those individuals received PSA for forest protection. In the absence of PSA and the Forestry Law's legal restrictions on forest land-use change, $10 \%$ of survey respondents receiving PSA would have harvested some timber, and $40 \%$ would have converted some of their forest to pasture or crops.
However, $50 \%$ of respondents with PSA did not intend to clear or harvest any forest. Environmental reasons were the primary motives given for retaining forest and included both watershed protection $(55 \%)$ and biodiversity conservation (39\%). Only $8 \%$ of PSA participants cited the legal restriction on forest clearing as a central motive in decisions to retain forest.

A modeled rate of natural forest loss of $-1.14 \% / y r$ was determined from the modified rate equation (Eqs. 2 and 3) and data indicating that $40 \%$ of individuals were interested in clearing forest after 1996. Assuming the absence of a ban on forest clearing, this equates to a $1.04 \%$ increase above the actual rate of natural forest loss observed in T2 and represents the retention of an additional $53 \mathrm{~km}^{2}$ of natural forest. PSA recipients with no interest in clearing or harvesting forest accounted for the retention of $80 \mathrm{~km}^{2}$ of natural forest.

Decision tree analysis indicated that the primary difference between PSA participants and nonparticipants was that those with PSA protection contracts had a lower dependence on income derived from agricultural activities on their farms, referred to hereafter as "farm dependence" (Table 2 ). This classification generated a low error rate (17.4\%) when differentiating PSA participants from nonparticipants. Nearly half of the PSA participants with forest protection contracts earned no income from their farms aside from PSA-derived income, whereas nonparticipants were often entirely dependent upon their farms for income. Further, $71 \%$ of participants with forest protection contracts were absentee landowners, whereas this was the case for $57 \%$ of nonparticipants who owned forest.

\section{Forest recruitment: reforestation}

Land-cover comparisons show that total forest cover, including all forest categories, increased within the Corridor over both time periods. A net gain in total forest cover of $0.5 \% / \mathrm{yr}$ occurred in $\mathrm{T} 1$ and $0.6 \% / y$ in T2 (Table 1 ). Additions to total forest cover in $\mathrm{T} 1$ were primarily from reforestation, accounting for $65 \%$ of the total forest cover gained. However, much of this gain was offset by a loss of natural forest that negated $60 \%$ of gains (Table 1). The land area in tree plantations increased consistently during the study period, from $19 \mathrm{~km}^{2}$ in 1986 to $268 \mathrm{~km}^{2}$ in 2001, although gains in forest 
Table 1. The amount of forest lost or gained during each time period and the annual rate of change estimated using the formula by Puyravaud (2003). $\Delta \mathrm{T} 1$ represents 1986-1996, and $\Delta \mathrm{T} 2$ represents 1996-2001. Net forest cover includes all five forest types.

\begin{tabular}{lcccc}
\hline \hline Forest cover type & $\Delta \mathrm{T} 1\left(\mathrm{~km}^{2}\right)$ & $\Delta \mathrm{T} 1 / \mathrm{yr}(\%)$ & $\Delta \mathrm{T} 2\left(\mathrm{~km}^{2}\right)$ & $\Delta \mathrm{T} 2 / \mathrm{yr}(\%)$ \\
\hline Natural forest & -179 & -1.43 & -12 & -0.10 \\
Reforestation & 194 & 24.15 & 55 & 4.57 \\
Charral & -42 & -2.25 & -60 & -8.93 \\
Secondary forest & 69 & 18.95 & 20 & 4.31 \\
Riparian forest & 36 & 5.21 & 48 & 8.66 \\
Net forest cover & 78 & 0.47 & 50 & 0.58 \\
\hline
\end{tabular}

cover attributable to reforestation were moderate during T2 (Fig. 2). Rate equation calculations indicate that tree plantation establishment slowed from $24 \% / \mathrm{yr}$ in $\mathrm{T} 1$ to $4.6 \% / \mathrm{yr}$ in T2 (Table 1 ). Continued recruitment of both tree plantations and secondary forests, as discussed below, coupled with reduced natural forest loss accounts for the larger net forest gain in $\mathrm{T} 2$ relative to $\mathrm{T} 1$.

Nearly one third of all landowners interviewed (31\%) maintained tree plantations on their farms, and the majority (60\%) were established through PSA reforestation contracts. Most reforested land was converted from pasture $(88 \%)$, whereas $12 \%$ was formerly crop land. Fifty-three percent of landowners indicated satisfaction with the level of PSA payments, with the remaining landowners claiming that payments did not meet expected costs. Of those with PSA, most (68\%) would not have reforested without payments to cover establishment and maintenance costs. A majority of landowners with PSA payments for reforestation (59\%) intended to plant another crop of trees after harvesting their current plantations, a quarter $(24 \%)$ indicated they would not replant, and $17 \%$ remained undecided until final harvests. Although there were few landowners reforesting without PSA $(n=22)$, similar patterns were observed within this group.

As observed from decision tree analysis, PSA participants with reforestation tended to be less farm dependent relative to program nonparticipants
(Table 2). The error rate was low $(22.4 \%)$ in differentiating PSA participants from nonparticipants in the reforestation program. Most PSA participants in reforestation were also absentee landowners $(82 \%)$, whereas most nonparticipants without reforestation lived on their farms $(67 \%)$.

\section{Forest recruitment: secondary vegetation}

Riparian forests contributed to newly recruited forest cover in the Corridor, increasing from 2 to $6 \%$ of the total land area during $\mathrm{T} 1$ and $\mathrm{T} 2$, respectively (Table 1). Forest clearing along perennial streams is prohibited in Costa Rica. Riparian forest remnants emerged during T1 in locations in which formerly contiguous natural forest was cleared close to waterways. An increase in post-1996 riparian forests was primarily through secondary forest recruitment along streams and rivers because few natural forests were cleared during this period.

Successional vegetation, including both secondary forest and charral, occupied between 8 and $10 \%$ of the Corridor area at any one point in time (Fig. 2). However, the land area occupied by secondary forest increased slightly after 1996, whereas the land area in charral declined from $9 \%$ in 1986 to $4 \%$ in 2001 (Fig. 3B). Although charral commonly succeeds abandoned pasture, the amount of pasture developing into charral was offset by a greater or 
Fig. 2. Mapped forest cover in the San Juan-La Selva Biological Corridor depicting landscape changes at each time interval using these forest categories: natural forest (dark green), forest regeneration of charral and secondary forest (bright green), and reforestation (orange).
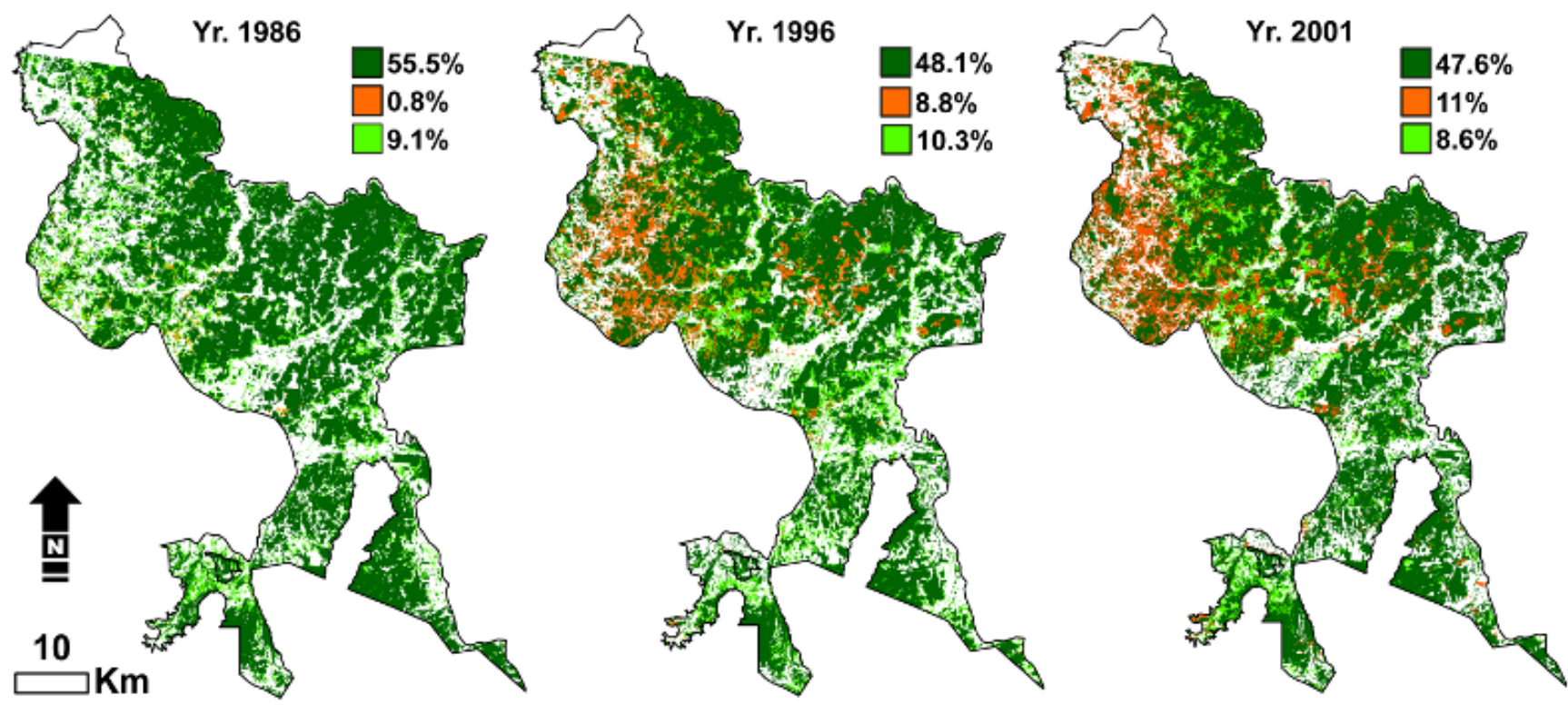

equal amount of charral returned to pasture in both T1 and T2 (Appendix 1). In addition to charral, land uses replacing pasture included secondary forest, crops, reforestation, and riparian forests during both T1 and T2 (Appendix 1).

The scarcity of charral observed in the land-cover data is corroborated by landowner surveys indicating that only $13 \%$ of respondents had charral on their property. Most charral (68\%) had previously been used as pasture and was maintained for both economic (56\%) and conservation (20\%) reasons. However, $43 \%$ of landowners intended to clear charral for pasture or agricultural use in the future.

Soil carbon pool size varied across land-use classes by depth. Pastures contained a greater amount of mineral soil carbon at $0-10 \mathrm{~cm}$ relative to charral and secondary forest, but there was high variability within land-use classes (Table 3). Mineral-soil carbon content in pastures rapidly decreased with depth, and both charral and secondary forests had significantly greater soil carbon contents than did pastures at depths of $10-30 \mathrm{~cm}$ (Table 3). Total soil carbon stocks from $0-30 \mathrm{~cm}$ did not vary across land-use classes (Table 3). Aboveground carbon stocks in secondary forests were relatively constant for the first 8-20 yr of development, although rapid gains in aboveground carbon were observed after 20-25 yr (Fig. 4).

\section{Forest and landscape connectivity}

Three fragmentation indices were used to quantify connectivity trends in the Corridor. Total forest cover, representing all forest-cover types combined, showed only minor changes in connectivity across indices over time (Table 4). Indices for individual forest types reflect a small decrease in natural forest connectivity and increased connection among forest types associated with forest recruitment (Table 4). Natural forests comprised the majority of total forest cover through time but became increasingly isolated, as indicated by higher isolation and lower aggregation (Table 4). Patterns in reforestation, 
Fig. 3. Area differences for each time interval for the five forest categories and two agricultural categories observed at (A) the extent of the study area $\left(6349 \mathrm{~km}^{2}\right)$ and (B) the San Juan-La Selva Biological Corridor $\left(2425 \mathrm{~km}^{2}\right)$. Dotted lines above the natural forest category show the top of the bar in year 2001.

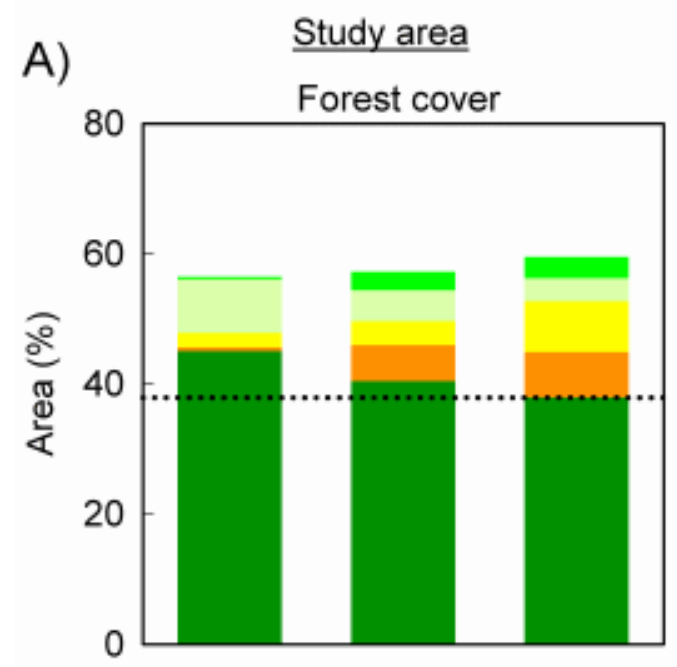

B)
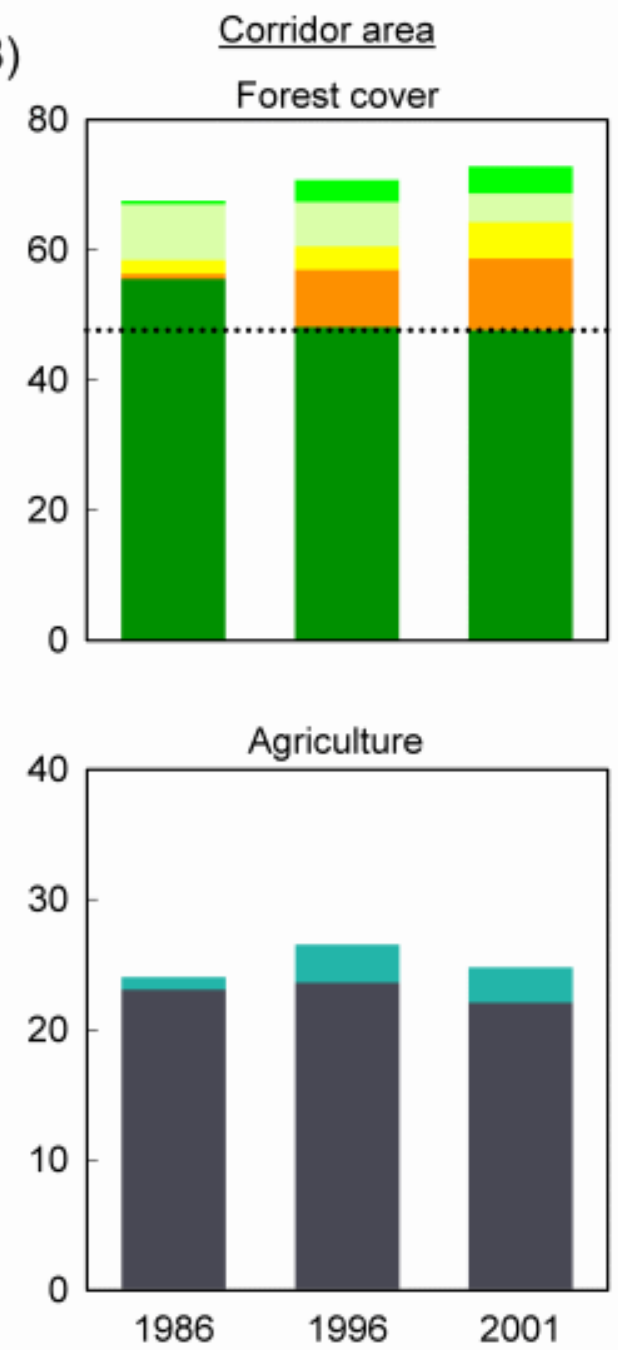

Secondary forest Charral Riparian forest Reforestation Natural forest

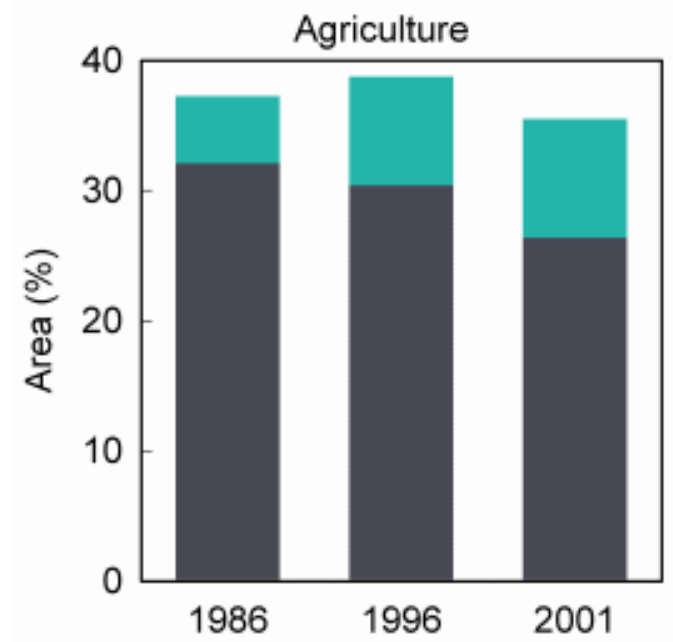

secondary forest, and riparian forest showed trends toward increased forest connectivity and aggregation (Table 4). Patches of reforestation and secondary forest regeneration were aggregated in a few areas of the Corridor, often adjacent to natural forest patches (Fig. 2). Cropland area increased in both T1 and T2, often replacing cattle pastures (Fig. 3A,B, Appendix 1).

\section{DISCUSSION}

\section{Natural forest retention}

Land-use trends in the Corridor are marked by changes in both environmental policies and socioeconomic conditions that favor natural forest retention. Restrictions on forest clearing were more effective in landscapes in which forest owners 
Table 2. The number of landowners with PSA (payment for environmental services) contracts for forest protection or reforestation, compared to the number of landowners eligible for these PSA programs. Landowners with more than 2 ha of forest land were considered eligible for the forest protection PSA program, and landowners with more than 1 ha of pasture or charral were considered eligible for the reforestation PSA program. Data are further broken down by the primary factor dividing PSA participants from nonparticipants as determined by decision tree analyses. The "break point" for farm dependence, i.e., the percentage of landowner income from agricultural activities on the farm, in each PSA program is determined through the analysis and, as a result, varies between programs. AI stands for agricultural income.

\begin{tabular}{llccc}
\hline \hline PSA program & & \multicolumn{2}{c}{ Primary decision tree division } \\
\hline Forest protection & & & $<66 \% \mathrm{AI}$ & $>66 \% \mathrm{AI}$ \\
& PSA & 72 & 61 & 11 \\
& No PSA & 37 & 8 & 29 \\
\multirow{5}{*}{ Reforestation } & & & $<25 \% \mathrm{AI}$ & $>25 \% \mathrm{AI}$ \\
& PSA & 38 & 29 & 9 \\
& No PSA & 96 & 21 & 75 \\
\hline
\end{tabular}

received PSA and dependence on farming for income was relatively low.

We observed a substantial reduction in forest loss and fragmentation in the Corridor, in which a high density of PSA contracts was established during T2, concurrent with implementation of the 1996 Forestry Law. In contrast, the area outside the Corridor continued to lose natural forest even after the adoption of the forest change restrictions of the 1996 Forestry Law, indicating that areas outside the Corridor not targeted by PSA remained vulnerable to some illegal forest clearing after 1996. Historically, environmental policies governing forest management and land use have not played a major role in reducing deforestation in Costa Rica (Kishor and Constantino 1993). Monetary compensation to landowners to protect natural forest through PSA appeared to increase forest retention in the Corridor beyond the protection provided by a legal ban on forest clearing.

Modeled forest loss within the Corridor indicates that as much as a $1 \%$ reduction in the annual rate of forest loss can be attributed to PSA and the 1996 Forestry Law. We consider this a realistic approximation of the impact of forest policies that combine land-use restrictions with compensation to landowners for environmental services, because half of the individuals interviewed expressed a desire to clear forest or harvest timber in the absence of policy reforms. For many landowners, payments or the potential to receive payments in the future were sufficient incentives to maintain natural forest that might otherwise be subjected to selective tree harvests or illegal clearing.

Following decades of deforestation driven by prior Costa Rican land-use policies intended to open the agricultural frontier, diversified economic opportunities including off-farm labor have been important in reducing deforestation rates (Butterfield 1994a,b, Schelhas and Sánchez-Azofeifa 2006). Our observations showed that the landowners in the Corridor who were most likely to participate in the PSA forest protection program had a low dependence on their farms for income. Reduced economic dependence on farming, a high degree of 
Table 3. Means of mineral soil carbon storage \pm one standard error across all land-use types and soil depths. Reported $P$-values and $F$-values were derived from individual ANOVAs performed for each soil depth. For each analysis, the numerator degrees of freedom were 2 and denominator degrees of freedom were 43. Different superscripted letters represent significant differences among categories, as determined by means separation.

\begin{tabular}{cccccc}
\hline \hline Soil depth (cm) & $\begin{array}{c}\text { Pasture soil carbon } \\
(\mathrm{Mg} / \mathrm{ha})\end{array}$ & $\begin{array}{c}\text { Charral soil carbon } \\
(\mathrm{Mg} / \mathrm{ha})\end{array}$ & $\begin{array}{c}\text { Secondary forest soil } \\
\text { carbon }(\mathrm{Mg} / \mathrm{ha})\end{array}$ & $P$-value & $F$-value \\
\hline $0-10$ & $43.00 \pm 2.90^{\mathrm{a}}$ & $34.65 \pm 2.31^{\mathrm{b}}$ & $35.70 \pm 1.13^{\mathrm{b}}$ & 0.012 & 6.91 \\
$10-20$ & $18.71 \pm 1.38^{\mathrm{a}}$ & $25.00 \pm 1.63^{\mathrm{b}}$ & $20.65 \pm 0.69^{\mathrm{c}}$ & 0.0048 & 0.0167 \\
$20-30$ & $12.60 \pm 0.65^{\mathrm{a}}$ & $17.53 \pm 1.63^{\mathrm{b}}$ & $14.57 \pm 0.73^{\mathrm{c}}$ & 7.51 \\
Total: $0-30$ & $74.32 \pm 4.02$ & $77.18 \pm 4.46$ & $70.92 \pm 2.02$ & 0.3659 & 1.03 \\
\hline
\end{tabular}

absentee forest ownership (52\%), and conservation motivations in the study landscape are indications of increasingly favorable socioeconomic conditions for natural forest protection. Of the landowners enrolled in PSA for forest protection, 60\% did not intend to convert forest to another land use. Many payments were made to protect forest land unlikely to be cleared; however, compensation to landowners providing environmental services is a principle objective of PSA (Pagiola 2008).

The legal prohibition of forest clearing, which restricted most other income-generating options for forested land, i.e., reduced opportunity costs, has made enrolment in the PSA program more economically attractive. Farm-dependent landowners with forest eligible for PSA within the Corridor represented 11 of 72 PSA participants $(15 \%)$ and 29 of 37 nonparticipants (78\%). Many farmdependant nonparticipants owned small $(<10$ ha) forest patches (Morse 2007), a factor that can decrease the economic attraction of PSA given the high transaction costs associated with enrolment (Pagiola et al. 2005). PSA for natural forest protection tends to favor large forest ownerships from the perspective of both landowners and forest regentes. This is because total payments are calculated on the basis of forest area protected, whereas the transaction costs of enrolment are similar for both large and small forests (Pagiola et al. 2005). Perceived ecological benefits associated with conserving large forest tracts may also increase the potential for large forests to come under PSA contract (Zbinden and Lee 2005). Although payment rates are adequate to motivate participation in PSA programs that help secure forest protection, program benefits do not appear to be evenly balanced among landowners in the Corridor. Specialized targeting and streamlined program requirements for smaller forest ownerships $(<50$ ha) may be necessary to reach these landowners and more equitably distribute program benefits in the future.

\section{Forest recruitment: reforestation}

Total forest cover, including all forest categories, increased in the Corridor during T1 and T2, mainly because of a large increase in tree plantations (Fig. 3B) established under PSA and earlier incentive programs. By 2001, tree plantations covered 268 $\mathrm{km}^{2}$ of the Corridor, a figure that compares favorably to the $\sim 380 \mathrm{~km}^{2}$ reported to have been planted regionally up to 2001, given tree mortality, plantation failure, and some initial harvests (Butterfield 1994a, COSEFORMA 1995, Méndez 2003). These results contrast somewhat with those of Schelhas and Sánchez-Azofeifa (2006), indicating that expanded cattle ranching via land consolidation and forest clearing limited widespread reforestation in a portion of the Corridor. Landcover data from our analysis indicate that the amount of reforested land increased dramatically but was aggregated in parts of the Corridor (Fig. 2). 
Fig. 4. Mean aboveground carbon storage \pm one standard error for each secondary-forest site. The solid and dotted horizontal lines represent mean aboveground carbon storage and one standard error, respectively, as measured in undisturbed primary forests at the La Selva Biological Station (Clark and Clark 2000).

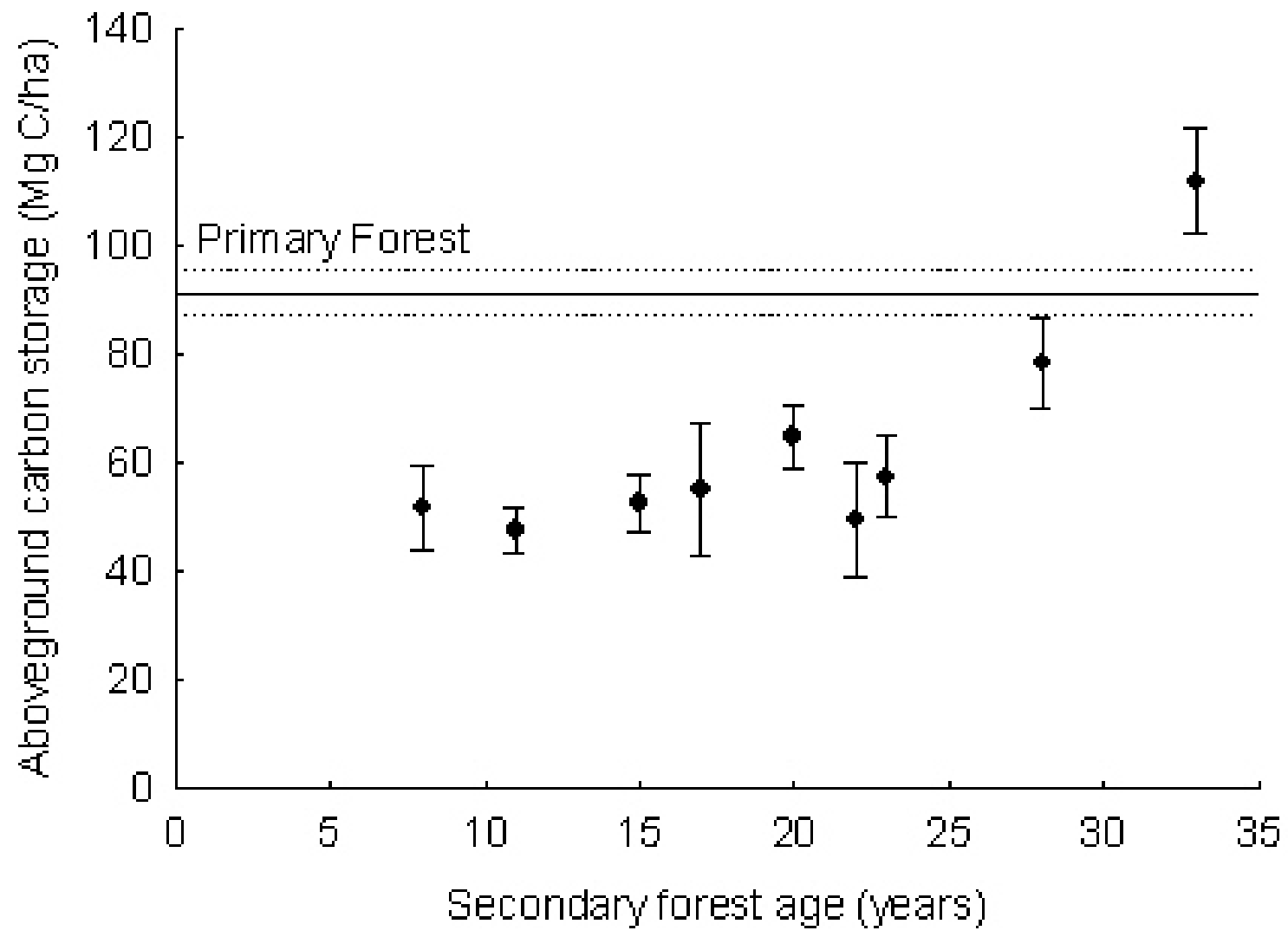

The rapid expansion of tree plantations observed from our land-cover data was fueled by incentives for reforestation that were first paid out in 1986, a pattern also reported by Watson et al. (1998). Without payments for reforestation, more than two thirds of the landowners receiving PSA would not have reforested. For some landowners, tree plantations have been adopted as a viable economic activity in this landscape, competitive with other agricultural land uses. The landowners benefiting from PSA for reforestation are primarily those with low dependence on their farms as a source of income. Our data suggest that reforestation payment rates are not adequate to motivate most farmdependent landowners to forgo current productions systems, i.e., the opportunity cost is too high. However, a recent increase in PSA reforestation payment rates and an extension of the payment period from 5 to $10 \mathrm{yr}$ (FONAFIFO 2008) may attract more farm-dependent landowners to the program, as well as retain those who found prior payment rates insufficient.

While providing an economic return to landowners, reforestation activities also contribute environmental services targeted by PSA. These services include increased soil carbon storage as well as biodiversity value as native trees, shrubs, and wildlife take advantage of plantation-provided habitat (Lamb et al. 1997, Silver et al. 2000, Cusack and Montagnini 
Table 4. Fragmentation indices for total forest cover combining all forest classes, and individual forest classes at each land-cover date. Euclidean nearest neighbor distance (ENN) was used to measure isolation, patch cohesion (PC) was used as an indicator for physical connectivity among like patches, and percentage of like adjacencies (PLA) was used as a measure of aggregation among similar patches.

\begin{tabular}{lcccccccccc}
\hline \hline & \multicolumn{3}{c}{ Isolation: ENN (m) } & \multicolumn{3}{c}{ Connectivity: PC (\%) } & \multicolumn{3}{c}{ Aggregation: PLA (\%) } \\
Category & 1986 & 1996 & 2001 & 1986 & 1996 & 2001 & 1986 & 1996 & 2001 \\
\hline Forest cover & 110.8 & 120.5 & 115.8 & 99.86 & 99.91 & 99.92 & 95.62 & 96.37 & 96.61 \\
Natural forest & 130.6 & 135.4 & 142.7 & 99.76 & 99.68 & 99.68 & 94.83 & 94.02 & 93.91 \\
Reforestation & 337.0 & 202.3 & 187.9 & 86.59 & 97.06 & 97.91 & 71.34 & 81.81 & 81.36 \\
Charral & 164.3 & 191.1 & 250.9 & 93.28 & 93.33 & 93.82 & 74.14 & 75.20 & 77.28 \\
Secondary forest & 526.4 & 215.7 & 227.9 & 83.46 & 89.09 & 92.68 & 67.39 & 70.48 & 74.05 \\
Riparian forest & 238.5 & 216.9 & 188.1 & 87.57 & 89.20 & 92.19 & 67.66 & 71.78 & 74.57 \\
\hline
\end{tabular}

2004). However, tree plantations are intended for harvest, i.e., clear-cut at a given rotation age, thus limiting the potential for sustained aboveground carbon storage and biodiversity habitat. Additionally, the conversion of tree plantations to other land uses is permitted, and our data show that not all landowners in the Corridor intend to replant trees following harvests given previous PSA rates. The long-term contribution of tree plantations to both forest cover and environmental services in this landscape is uncertain.

\section{Forest recruitment: secondary vegetation}

The low levels of secondary forest establishment in the Corridor and larger study area do not follow patterns of agricultural abandonment conducive to forest recruitment encountered elsewhere in Costa Rica (Arroyo-Mora et al. 2005). Our land-cover data show that forest recruitment via secondary succession may represent only temporary gains in connectivity and short-lived opportunities for habitat restoration important to biodiversity conservation. A decline in land area occupied by charral over time (Table 1) indicates that landowners abandoned very little pasture during the study period.

Landowner survey data support the observation that much of the land converted to charral or secondary forest during our study period was previously pasture (Appendix 1). Although charral and secondary forest occupy a small amount of land area, these land-use types are ecologically important as sites for native tree species recruitment, carbon sequestration, and habitat restoration (Holl and Kapelle 1999). Charral typically persists on abandoned land for a short period of time $(<10 \mathrm{yr})$ before a tree canopy develops, but the 1996 Forestry Law's legal definition of forest provides a perverse incentive for landowners to inhibit the development of secondary forest (Sierra and Russman 2006). Because landowners planned to clear nearly half of existing charral for pasture or agriculture, the potential habitat value and future carbon storage on these sites is limited.

Transitions from pasture to secondary forest reveal differences in soil carbon pools at shallow depths, a finding that is not surprising given that surface soils have high carbon turnover rates in the humid tropics (Veldkamp 1994). This attribute facilitates a relatively rapid alteration of carbon pool size in response to changing land uses and attendant shifts in carbon inputs and turnover. The increase in soil carbon pool size found in charrals at a depth of 10$30 \mathrm{~cm}$ likely occurs from shifts in rooting depth and subsequent alteration of organic carbon inputs to the soil at an early successional phase (Jackson et al. 1996, Jobbágy and Jackson 2000). A decline in soil carbon pool size at these depths in secondary forest 
relative to charral was not unexpected, because these sites were dominated by more deeply rooted trees. Although the distribution of carbon in the top $30 \mathrm{~cm}$ of soil varied among land-use types, the total amount of carbon stored in surface soils across landuse types did not vary significantly.

Shifts in soil carbon pools following land-use transitions are commonly documented in the tropics. These changes occur in surface soils (Rhoades et al. 2000, Feldpausch et al. 2004, Powers 2004), as well as in deep mineral soils (Veldkamp et al. 2003). However, other factors influencing the amount of carbon stored and retained in a soil include soil mineralogy and topography. Mineralogy is critical in this region of Costa Rica because soils contain a large amount of mineral-stabilized carbon, and this feature likely reduces carbon losses in surface soils following land-use transitions (Powers and Veldkamp 2005, Schedlbauer and Kavanagh 2008)

Aboveground carbon stocks rapidly increased toward the values observed in primary forest following secondary forest establishment on former pastures. Secondary forest stands appear to pass through a period of low biomass accumulation and reach the point of stem exclusion after 20-25 yr of development (Fig. 4). Following this phase, secondary forests aged 25-30 yr had aboveground carbon stocks equivalent to those in primary forests of the region (Fig. 4, Clark and Clark 2000). Given the legal restriction on clearing forest land, developing secondary forests have significant potential for long-term carbon storage and merit greater attention from forest management and policy perspectives (Chazdon 2008).

In addition to carbon storage, benefits accruing from secondary forest recruitment include forest structural connectivity, natural habitat development, and new timber resources (Finegan 1992, Lamb et al. 1997). Secondary forests provide a number of potential economic and restoration opportunities that contribute positively to the goals of the San Juan-La Selva Biological Corridor. Our landowner data indicate that forest policies and incentives have effectively influenced land-use decisions to establish tree plantations, and similar incentives could increase secondary forest recruitment. Opportunity costs associated with the establishment and retention of secondary forests differ from those of tree plantations. Specifically, the development of secondary forest results in a permanent ban on forest clearing, thus altering the time interval a landowner considers in his or her opportunity-cost calculations. Because of these differences, payment structure and implementation should be tailored to landowner needs and forest management objectives (Kammesheidt 2002). The recent introduction of PSA for natural regeneration (FONAFIFO 2008) represents progress in acknowledging the benefits of secondary forest, although the program remains confined to western Costa Rica.

\section{Forest and landscape connectivity}

Greater natural forest retention in T2 and recruitment throughout the study period clearly helped maintain forest connectivity in the Corridor and, subsequently, between protected areas in Costa Rica and Nicaragua. The data presented above confirm the role of the 1996 Forestry Law and prior reforestation programs in the maintenance of forest connectivity critical to biodiversity conservation. A combination of socioeconomic conditions favorable to natural forest retention, landowner decisions to participate in PSA programs, and legal restrictions have increasingly affected the extent to which forest is retained or re-established to connect forest habitats in this landscape. Although monocultures of fast-growing exotic species occupy many of the reforested areas, a recent shift toward native tree species has occurred. Native species plantations have the potential to support diverse understory flora (Cusack and Montagnini 2004) and attract wildlife (Lamb et al. 1997), but the homogeneity of tree plantations may detract from natural forest connectivity. During T1, tree plantations with low species and structural diversity replaced natural forests on some sites. A continuation of this process in T2 was primarily an artifact of natural forest areas being misclassified as tree plantations in some locations in which plantations had reached advanced developmental stages and bordered natural forest (Appendix 1). Natural forest, tree plantations close to final harvest, and secondary forest became aggregated in T2, with increasingly interlocked forest canopies and similar height structures (Fig. 2).

Secondary forests play a role in maintaining forest connectivity, often developing on land adjacent to natural forests (Fig. 2). Increases in riparian forest cover through secondary regeneration in T2 also contributed to connectivity in the Corridor. The benefits of secondary forest cover on the landscape, 
in terms of connectivity, biodiversity value, and carbon services, may outweigh those of tree plantations in light of 1996 Forestry Law objectives. As secondary vegetation reaches a successional stage with at least 60 tree stems $>15 \mathrm{~cm} \mathrm{dbh} / \mathrm{ha}$, it is legally classified as forest and can no longer be cleared for alternate land uses. Because plantations are harvested on short rotations and can be legally converted to nonforest uses, retaining new forest through secondary succession is more likely to provide a permanent addition to forest cover.

Many of Costa Rica's recognized corridor areas resemble stepping stones of forest habitat in agriculturally dominated landscapes with low tree cover. The effect of the 1996 Forestry Law on forest connectivity in conjunction with the other data reported here reflects on the emerging importance of forest recruitment via multiple pathways. As natural forests were replaced by reforestation or secondary forests, a fundamental change in forest structural connectivity occurred. This highlights the need to examine the functional role of these new forest connections in which forest cover is best characterized as a mosaic of habitats with variable economic and ecological potential.

\section{CONCLUSION}

Costa Rica's innovative strategies to maintain private forest land and environmental services made notable progress toward these goals in the San JuanLa Selva Biological Corridor. Following the introduction of PSA and the 1996 Forestry Law, we observed a reduction in forest loss coupled with an increase in reforestation activities. Targeting of PSA in the Corridor was also linked to the maintenance of forest connectivity over time. In contrast, areas not targeted for PSA continued to lose natural forest to illegal clearing after 1996. Landowner survey data indicated that PSA and the 1996 Forestry Law, in conjunction with socioeconomic conditions favorable for natural forest retention, played central roles in the observed changes in land cover. Additional factors, including the existence of national NGOs facilitating PSA contracts with landowners in the Corridor, may have influenced observed land-cover changes. Strong institutional support and infrastructure to implement PSA programs likely contributed to the improved forest retention and recruitment patterns observed in the Corridor.
PSA payments for both forest protection and reforestation primarily benefited landowners with low dependence on their farms for income. Future targeting of PSA could be directed at farmdependent landowners as a way to equitably expand program benefits to new participants. Given declining rates of reforestation in the Corridor and the uncertainty of some landowners about replanting trees, improved PSA incentives may be crucial to maintaining reforestation as a viable landuse activity. Ongoing adjustments of PSA, including the recent national increase in reforestation payment rates, are likely to maintain program viability. Additional adaptation of PSA to encourage forest restoration in naturally regenerating areas could help counteract potential incentives to clear secondary forest. Secondary forests have demonstrated environmental service values by providing desired carbon sequestration services and habitat for biodiversity, and they could also enhance forest connectivity within the Corridor.

PSA program changes such as the protection payments for natural regeneration recently implemented in western Costa Rica will continue to provide flexibility in tailoring the program to diverse and changing landscape and socioeconomic conditions. As a case study, the Costa Rican experience with PSA provides evidence that environmental service payments in conjunction with a legal ban on forest conversion are effective in retaining natural forest and recruiting new forest cover when focused in priority conservation areas like the Corridor. The PSA program has been tailored to fit Costa Rica's socioeconomic conditions but shows promise as an effective conservation approach. Adaptations of PSA such as those recommended above suggest ways in which this approach can be made effective in other settings.

Responses to this article can be read online at: http://www.ecologyandsociety.org/voll4/iss 1/art23/ responses/

\section{Acknowledgments:}

This research is based on the collaborative dissertation research of the first three authors; they have all contributed equally and are listed alphabetically. Research was supported in part by NSF-IGERT grant no. 0114304. Thanks for 
assistance are due to Edwin Pereira, Marvin Zamora, Vicente Herra, José Manuel Ulate, Sandra Candela, Isabel Venegas, Zayra Ramos, Hugo Brenes, Germán Obando, Andrés Sanchún, Pablo Acuna, Oscar Quirós, Jhonny Méndez, Nelson Zamora, Robin Chazdon, and Juan Pablo Arroyo. We are also indebted to the organizations FUNDECOR and CODEFORSA as well as numerous landowners in the study area. We thank two anonymous reviewers for comments important to improving this manuscript.

\section{LITERATURE CITED}

Arroyo-Mora, J. P., G. A. Sánchez-Azofeifa, B. Rivard, J. C. Calvo, and D. H. Janzen. 2005. Dynamics in landscape structure and composition for the Chorotega region, Costa Rica from 1960 to 2000. Agriculture, Ecosystems and Environment 106:27-39.

Butterfield, R. P. 1994a. Forestry in Costa Rica: status, research priorities, and the role of the La Selva Biological Station. Pages 317-328 in L. A. McDade, K. S. Bawa, H. A. Hespenheide, and G. S. Hartshorn, editors. La selva: ecology and natural history of a neotropical rain forest. University of Chicago Press, Chicago, Illinois, USA.

Butterfield, R.P. $1994 b$. The regional context: land colonization and conservation in Sarapiquí. Pages 299-306 in L. A. McDade, K. S. Bawa, H. A. Hespenheide, and G. S. Hartshorn, editors. La Selva: ecology and natural history of a neotropical rain forest. University of Chicago Press, Chicago, Illinois, USA.

Chassot, O., and G. Monge. 2002. Corredor Biológico San Juan-La Selva: ficha técnica. Centro Científico Tropical, San José, Costa Rica.

Chave, J., C. Andalo, S. Brown, M. A. Cairns, J. Q. Chambers, D. Eamus, H. Fölster, F. Fromard, N. Higuchi, T. Kira, J.-P. Lescure, B. W. Nelson, H. Ogawa, H. Puig, B. Riéra, and T. Yamakura. 2005. Tree allometry and improved estimation of carbon stocks and balance in tropical forests. Oecologia 145:87-99.

Chazdon, R. L. 2008. Beyond deforestation: restoring forests and ecosystem services on degraded lands. Science 320:1458-1460.

Chomitz, K. M., E. Brenes, and L. Constantino. 1999. Financing environmental services: the Costa Rican experience and its implications. Science of the Total Environment 240:157-169.

Clark, D. B., and D. A. Clark. 2000. Landscapescale variation in forest structure and biomass in a tropical rain forest. Forest Ecology and Management 137:185-198.

Costa Rican Institute of Technology (ITCR). 2004. Digital atlas of Costa Rica. ITC, Cartago, Costa Rica.

Cusack, D., and F. Montagnini. 2004. The role of native species plantations in recovery of understory woody diversity in degraded pasturelands of Costa Rica. Forest Ecology and Management 188:1-15.

Defries, R., A. Hansen, A. C. Newton, and M. C. Hansen. 2005. Increasing isolation of protected areas in tropical forests over the past twenty years. Ecological Applications 15:19-26.

Department for International Development (DFID). 2003. Sustainable livelihoods guidance sheets. DFID, London, UK.

Feldpausch, T. R., M. A. Rondon, E. C. M. Fernandes, S. J. Riha, and E. Wandelli. 2004. Carbon and nutrient accumulation in secondary forests regenerating on pastures in central Amazonia. Ecological Applications 14:S164-S176.

Ferraro, P. J., and A. Kiss. 2002. Direct payments to conserve biodiversity. Science 298:1718-1719.

Finegan, B. 1992. The management potential of neotropical secondary lowland rain forest. Forest Ecology and Management 47:295-321.

Fondo Nacional de Financiamiento Forestal (FONAFIFO). 2008. Servicios Ambientales, estadísticas PSA 1997-2005. Available online at: http://www.fonafifo.com/paginas espanol/ servicios ambientales/sa estadisticas.htm.

Forestry Development Commission of San Carlos (COSEFORMA). 1995. Archivo de plantaciones forestales establecidas en la región Huertar Norte de Costa Rica del período 19791995 de incentivos CAF-CAFA Articulo 87 Renta- 
FDF. COSEFORMA, San José, Costa Rica.

Holdridge, L. R. 1967. Life zone ecology. Tropical Science Center, San José, Costa Rica.

Holl, K. D., and M. Kappelle. 1999. Tropical forest recovery and restoration. Trends in Ecology and Evolution 14:378-379.

Jackson, R. B., J. Canadell, J. R. Ehleringer, H. A. Mooney, O. E. Sala, and E. D. Schulze. 1996. A global analysis of root distributions for terrestrial biomes. Oecologia 108:389-411.

Jobbágy, E. G., and R. B. Jackson. 2000. The vertical distribution of soil organic carbon and its relation to climate and vegetation. Ecological Applications 10:423-436.

Kammesheidt, L. 2002. Perspectives on secondary forest management in humid lowland America. AMBIO 31:243-250.

Kishor, N. M., and L. F. Constantino. 1993. Forest management and competing land uses: an economic analysis for Costa Rica. LATEN Dissemination Note No. 7. World Bank, Washington, D.C., USA.

Lamb, D., J. Parrotta, R. Keenan, and N. Tucker. 1997. Rejoining habitat remnants: restoring degraded rainforest lands. Pages 366-385 in W. F. Laurance, and R. O. Bierregaard, editors. Tropical forest remnants: ecology, management, and conservation of fragmented communities. University of Chicago Press, Chicago, Illinois, USA.

Loh, W., and Y. Shih. 1996. Split selection methods for classification trees. Statistica Sinica 7:815-840.

Lu, D., P. Mausel, E. Brondízio, and E. Moran. 2003. Change detection techniques. International Journal of Remote Sensing 25:2365-2407.

Méndez, J. 2003. Pagos por servicios ambientales en la región Huetar Norte. Pages 2-3 in G. S. Jiménez, and M. E. H. Ugalde, editors. Costa Rica forestal: boletín informativo de la Oficina Nacional Forestal, No. 1. Oficina Nacional Forestal, Belén, Costa Rica.

Millennium Ecosystem Assessment. 2005. Ecosystems and human well-being: synthesis. Island Press, Washington, D.C., USA.
Ministry of Environment and Energy (MINAE). 2003. Mitos y realidades de la deforestación en Costa Rica. MINAE, San José, Costa Rica.

Miranda, M., I. T. Porras, and M. L. Moreno. 2003. The social impacts of payments for environmental services in Costa Rica: a quantitative field survey and analysis of the Virilla watershed. International Institute for Environmental Development, London, UK.

Morse, W. C. 2007. Payments for environmental services in Costa Rica: conservation and production decisions within the San Juan-La Selva Biological Corridor. Dissertation. University of Idaho, Moscow, Idaho, USA and Centro Agronómico Tropical de Investigación y Enseñanza (CATIE), Turrialba, Costa Rica.

Pagiola, S. 2008. Payments for environmental services in Costa Rica. Ecological Economics 65:721-724.

Pagiola, S., A. Arcenas, and G. Platais. 2005. Can payments for environmental services help reduce poverty? An exploration of the issues and the evidence to date from Latin America. World Development 33:237-253.

Pagiola, S., J. Bishop, and N. Landell-Mills, editors. 2002. Selling forest environmental services: market-based mechanisms for conservation development. Earthscan, London, UK.

Pedroni, L. 2003. Improved classification of Landsat Thematic Mapper data using modified prior probabilities in large and complex landscapes. International Journal of Remote Sensing 24:91-113.

Pinheiro, J. C., and D. M. Bates. 2000. Mixedeffects models in S and S-Plus. Springer-Verlag, New York, New York, USA.

Powers, J. S. 2004. Changes in soil carbon and nitrogen after contrasting land-use transitions in northeastern Costa Rica. Ecosystems 7:134-146.

Powers, J. S., and E. Veldkamp. 2005. Regional variation in soil carbon and $\delta^{13} \mathrm{C}$ in forests and pastures of northeastern Costa Rica. Biogeochemistry 72:315-336.

Puyravaud, J.-P. 2003. Standardizing the calculations of the annual rate of deforestation. 
Forest Ecology and Management 177:593-596.

R Core Development Team. 2008. $R$ : a language and environment for statistical computing. $\mathrm{R}$ Foundation for Statistical Computing, Vienna, Austria.

Read, J. M., J. S. Denslow, and S. M. Guzman. 2001. Documenting land cover history of a humid tropical environment in northeastern Costa Rica using time-series remotely sensed data. Pages 69-89 in A. C. Millington, S. J. Walsh, and P. E. Osborne, P.E., editors. GIS and remote sensing applications in biogeography and ecology. Kluwer Academic, Boston, Massachussets, USA.

Rhoades, C. C., G. E. Eckert, and D. C. Coleman. 2000. Soil carbon differences among forest, agriculture, and secondary vegetation in lower montane Ecuador. Ecological Applications 10:497-505.

Salant, P., and D. A. Dillman. 1994. How to conduct your own survey. Wiley, New York, New York, USA.

Schedlbauer, J. L., and K. L. Kavanagh. 2008. Soil carbon dynamics in a chronosequence of secondary forests in northeastern Costa Rica. Forest Ecology and Management 255:1326-1335.

Schedlbauer, J. L., S. E. Sesnie, and W. C. Morse. 2008. Efficacy of environmental service payments for forest conservation in Costa Rica's San JuanLa Selva Biological Corridor. Basins and Coasts News 2:31-35.

Schelhas, J., and G. A. Sánchez-Azofeifa. 2006. Post-frontier forest change adjacent to Braulio Carrillo National Park, Costa Rica. Human Ecology 34:407-431.

Sesnie, S. E., P. E. Gessler, B. Finegan, and S. Thessler. 2008. Integrating Landsat TM and SRTM-DEM derived variables with decision trees for habitat classification and change detection in complex neotropical environments. Remote Sensing of Environment 112:2145-2159.

Sierra, R., and E. Russman. 2006. On the efficiency of environmental service payments: a forest conservation assessment in the Osa Peninsula, Costa Rica. Ecological Economics 59:131-141.
Silver, W. L., R. Ostertag, and A. E. Lugo. 2000. The potential for carbon sequestration through reforestation of abandoned tropical agricultural and pasture lands. Restoration Ecology 8:394-407.

Snider, A. G., S. K. Pattanayak, E. O. Sills, and J. L. Schuler. 2003. Policy innovations for private forest management and conservation in Costa Rica. Journal of Forestry 101:18-23.

Veldkamp, E. 1994. Organic carbon turnover in three tropical soils under pasture after deforestation. Soil Science Society of America Journal 58:175-180.

Veldkamp, E., A. Becker, L. Schwendenmann, D. A. Clark, and H. Schulte-Bisping. 2003. Substantial labile carbon stocks and microbial activity in deeply weathered soils below a tropical wet forest. Global Change Biology 9:1171-1184.

Watson, V., S. Cervantes, C. Castro, L. Mora, M. Solis, I. T. Porras, and B. Cornejo. 1998. Making space for better forestry: policy that works for forest and people. Centro Cientifico Tropical and the International Institute for Environment and Development, San José, Costa Rica and London, UK.

Zbinden, S., and D. R. Lee. 2005. Paying for environmental services: an analysis of participation in Costa Rica's PSA program. World Development 33:255-272. 
Appendix 1. Land-cover change matrices in the San Juan-La Selva Biological Corridor demonstrating area changes $\left(\mathrm{km}^{2}\right)$ from one category to another for the periods 1986 to 1996 and 1996 to 2001, as determined from classified Landsat TM images. Difference estimates for each column indicate a net loss (-) or gain between dates for each land-cover category. Numbers in bold along the main diagonal are the amount of area without change. RF stands for reforested area; SF, secondary forest; NF, natural forest.

Table A1-1. Land-cover changes from 1986 to 1996.

\begin{tabular}{lcccccccc}
\hline \hline & Clouds & Crops & Pasture & Riparian & RF & Charral & SF & NF \\
\hline Clouds & $\mathbf{0}$ & 0.1 & 3 & 0.1 & & 0.4 & 0.1 & 1.9 \\
Crops & 9.5 & $\mathbf{3 . 5}$ & 35.8 & 1.7 & 0.2 & 6 & 0.6 & 12 \\
Pasture & 54.4 & 11.7 & $\mathbf{3 2 7 . 5}$ & 11.7 & 3.8 & 71.7 & 2.1 & 83.2 \\
Riparian & 12.7 & 0.7 & 21.1 & $\mathbf{6 . 8}$ & 1 & 10.3 & 0.4 & 32.9 \\
RF & 50.1 & 0.7 & 47.9 & 1.4 & $\mathbf{6 . 6}$ & 36.1 & 2 & 67.4 \\
Charral & 13.6 & 2.5 & 51.7 & 6.1 & 2.4 & $\mathbf{2 7}$ & 1.3 & 56.9 \\
SF & 7.9 & 0.8 & 13.8 & 2.1 & 1.2 & 13.2 & $\mathbf{1 . 2}$ & 40.5 \\
NF & 7.5 & 2.9 & 46.1 & 16.9 & 3.7 & 41 & 4.3 & $\mathbf{1 0 3 8 . 2}$ \\
Difference & -154.7 & 47 & 13.2 & 35.6 & 193.9 & -42 & 69.4 & -179 \\
\hline
\end{tabular}

Table A1-2. Land-cover changes from 1996 to 2001.

\begin{tabular}{lcccccccc}
\hline \hline & Clouds & Crops & Pasture & Riparian & RF & Charral & SF & NF \\
\hline Clouds & $\mathbf{0}$ & 0.2 & 2.5 & 0.5 & 0.8 & 0.4 & 0.1 & 2.8 \\
Crops & 0.4 & $\mathbf{1 6}$ & 27 & 3.7 & 3.6 & 4.8 & 1.5 & 6 \\
Pasture & 2.9 & 30.1 & $\mathbf{3 7 4 . 6}$ & 15.7 & 27.2 & 43 & 8.3 & 23.6 \\
Riparian & 0.4 & 4.1 & 39.6 & $\mathbf{2 3 . 1}$ & 9.3 & 18.9 & 3.8 & 28.7 \\
RF & 0.4 & 5.8 & 39.6 & 14.7 & $\mathbf{1 0 2 . 7}$ & 21.3 & 11.7 & 70 \\
Charral & 0.3 & 3.5 & 28.9 & 6.1 & 22.2 & $\mathbf{2 0 . 9}$ & 7.1 & 15.2 \\
SF & 0.6 & 2.5 & 17.8 & 3.3 & 11.5 & 13.9 & $\mathbf{1 2 . 8}$ & 37.1 \\
NF & 0.5 & 6.4 & 33.5 & 18.4 & 35 & 38.7 & 35.7 & $\mathbf{9 7 6 . 8}$ \\
Difference & 1.4 & -4.5 & -37.1 & 47.5 & 54.7 & -59.9 & 19.7 & -11.7 \\
\hline
\end{tabular}

